\title{
Radon emissions in Harju County, North Estonia
}

\author{
Krista Jüriado $^{\mathrm{a} \bowtie}$, Valter Petersell $^{\mathrm{b}}$, and Anto Raukas ${ }^{\mathrm{c}}$ \\ a Tallinn University, Narva mnt 25, 10120 Tallinn, Estonia \\ ${ }^{\mathrm{b}}$ Geological Survey of Estonia, Kadaka tee 82, 12618 Tallinn, Estonia \\ ${ }^{c}$ Institute of Ecology at Tallinn University, Uus-Sadama 5, 10120 Tallinn, Estonia \\ ${ }^{凶}$ Corresponding author, krysta@tlu.ee
}

Received 23 May 2011, revised 8 July 2011

\begin{abstract}
The risk of radon emissions is high in Estonia, especially in the northern part of the country where graptolite argillite (Dictyonema shale) crops out close to the ground surface. The behaviour and concentration of $\mathrm{Rn}$ in soil air vary considerably due to several reasons. To elucidate these, investigations were carried out in densely populated Harju County where the concentration of $\mathrm{Rn}$ is generally high and the risk to human health is the greatest. The investigations of soil air and in soil samples from the bottom of the excavations were carried out in 31 points. The assessments were made on the results of two simultaneously applied methods: calculated from eU concentration in soil measured with a gamma ray spectrometer, and by direct measurements in soil air with a Markus-10 emanometer. The results obtained by the two methods can notably differ.

In the high and very high $\mathrm{Rn}$ risk areas the concentration of $\mathrm{Rn}$ in the indoor air of dwellings was high as well. The main source of Rn there is the soil underneath the dwellings and/or bedrock, primarily radioactive graptolite argillite lying below the Quaternary deposits. Areas of such high Rn concentrations in the ground did not follow the genetic-lithologic types of Quaternary deposits. In the high Rn-risk areas within the klint zone the content of U, F, Mo, and some other elements exceeded the recommended and even permissible level for residential areas in several investigation points.
\end{abstract}

Key words: radon, uranium, klint area, soil air, graptolite argillite.

\section{INTRODUCTION}

Radon $(\mathrm{Rn})$ is a source of natural ionizing radiation, it is a toxic element causing mutations, especially lung cancer (Naturally ..., 2000; Mjönes \& Falk, 2005). Radon occurs in air and water as a colourless and odourless noble gas. It solidifies at $-71^{\circ} \mathrm{C}$ and decays into seven highly radioactive metals.

In the Baltic States the first investigations of Rn were carried out in 1997 1998 by Valter Petersell at the Geological Survey of Estonia. More detailed investigations of $\mathrm{Rn}$ in soil were launched in 2000; in 2002-2008 they were continued in cooperation with Swedish geologists in 566 observation points (Petersell et al., 2005).

In Estonia Rn risk is among the highest in Europe. In the process of compiling the small-scale $(1: 500$ 000) Rn-risk map of Estonia (Petersell et al., 2005) it appeared that grounds with high and very high $\mathrm{Rn}$ content $\left(50-250 \mathrm{kBq} / \mathrm{m}^{3}\right.$ and 
K. Jüriado et al.

$>250 \mathrm{kBq} / \mathrm{m}^{3}$, respectively) are frequent in northern Estonia. Such areas cover several square kilometres, mostly in the klint zone. According to the Estonian Radiation Protection Centre (unpublished data), in areas of high and very high $\mathrm{Rn}$ risk the concentration of $\mathrm{Rn}$ in indoor air often exceeds the permissible level $\left(200 \mathrm{~Bq} / \mathrm{m}^{3}\right)$, reaching $3000 \mathrm{~Bq} / \mathrm{m}^{3}$, sometimes even $10000 \mathrm{~Bq} / \mathrm{m}^{3}$.

In Estonia the Rn level in soil air and its behaviour are highly variable, but at the same time the sources of $\mathrm{Rn}$, its formation, reasons of $\mathrm{Rn}$ concentrations and dispersion, and regularities are still poorly investigated. The main source of $\mathrm{Rn}$ in indoor air is the soil beneath the buildings and the underlying loose sediments and bedrock of variable composition. Therefore, inappropriate assessment of Rn in soil air and its migration regularities may cause health disorders. On the other hand, uncertainty about $\mathrm{Rn}$ risk may generate emotional stress and cause unfounded material expenses. To at least partially find solutions to these problems, the authors chose for the study densely populated Harju County in northern Estonia, where the $\mathrm{Rn}$ risk level is high and all potential sources of $\mathrm{Rn}$ are present in the geological succession. In the klint escarpment radioactive graptolite argillite (Dictyonema shale) and obolus phosphorite crop out. Their clasts and smalls are scattered everywhere. Within the study area with high Rn risk several towns (Tallinn, Paldiski, Keila, Saue, Maardu, Kehra, Loksa), other settlements, and farmsteads are situated.

The factual material of the current paper originates from the databases of $\mathrm{Rn}$ risk-maps (Petersell et al., 2005, 2008), but includes also the new data collected by the authors in 2009 and 2010. The content of K, U, P, and Mo in the samples was determined in AcmeLabs, Canada, and that of eU, eTh, and $\mathrm{K}\left({ }^{40} \mathrm{~K}\right)$ in the laboratories of the Estonian Radiation Protection Centre and Geological Survey of Estonia.

\section{MATERIAL AND METHOD}

\section{Investigation area}

Harju County borders on the Gulf of Finland in the north (Fig. 1). With its area of $4333 \mathrm{~km}^{2}$ and 522252 residents (in 2003) it is the largest and most densely (120.8 inhabitants per $\mathrm{km}^{2}$ ) populated county in Estonia.

The topography is mostly flat. The North-Estonian Klint, a $10-30 \mathrm{~m}$ high west-east oriented escarpment, divides the county into two regions with different geological setting: the Fore-klint Lowland in the north and the Harju Limestone Plateau in the south. The geology is diversified by deep ancient valleys cutting into the sedimentary bedrock and filled with Quaternary deposits (Miidel \& Tavast, 1978; Raukas \& Tavast, 1987; Vaher et al., 2010).

In the succession three rock complexes overlying one another can be distinguished: Proterozoic crystalline basement is overlain by Palaeozoic sedimentary rocks and these in turn by loose Quaternary deposits (Raukas \& Teedumäe, 1997). Quaternary deposits contain to a greater or lesser extent crushed particles of the first two rock complexes. The radioactivity of all these rock types of different age and composition is variable. 
Among the crystalline basement rocks, the granites of the rapakivi formation cropping out on the bottom of the Gulf of Finland and in southern Finland are noteworthy. These rocks contain $3-10 \mathrm{~g} / \mathrm{t}$ of $\mathrm{U}, 10-50 \mathrm{~g} / \mathrm{t}$ of $\mathrm{Th}$, and $2.2-3.5 \%$ of K (Geological Survey of Finland, 1992). Their crushed varieties are found in till and other Quaternary deposits.

The surface of the crystalline basement and the Palaeozoic sedimentary rocks have a southward inclination of ca $3 \mathrm{~m} / \mathrm{km}$. In the Fore-klint Lowland the Quaternary cover is underlain by Cambrian sandstones, siltstones, and clay, and on the limestone plateau, by Ordovician limestones, less frequently by marls and dolostones. Limestones are often karstified.

Between the Cambrian sand- and siltstones and Ordovician limestones occur the major sources of Rn: Lower-Ordovician obolus sandstone with P-rich layers of phosphorite that are overlain by graptolite argillite. Both these rocks are rich in $\mathrm{U}$ and have a background Th content. Alongside $\mathrm{U}$, the two rock types contain also other environmentally hazardous elements (Table 1).

Between Narva and the Pakri Islands, in the klint and in the valleys cutting into the bedrock, graptolite argillite and phosphorite rich in $\mathrm{U}$ are exposed or spread beneath the Quaternary cover. Further to the west, these rocks crop out on the bottom of the Gulf of Finland. Their clasts and smalls are found in various glacial and marine deposits and serve as the main sources of Rn hazard and elevated natural radiation.

Table 1. Average concentration of radioactive and some other elements in graptolite argillite and phosphorite (Petersell et al., 2008)

\begin{tabular}{|c|c|c|c|c|c|}
\hline \multirow[t]{2}{*}{ Element } & \multicolumn{4}{|c|}{ Regions } & \multirow{2}{*}{$\begin{array}{c}\text { Earth } \\
\text { crust } \\
\text { average }^{b}\end{array}$} \\
\hline & $\begin{array}{c}\text { Western } \\
\text { Harju } \\
\text { County }\end{array}$ & Maardu & Kuusalu & $\begin{array}{c}\text { Parent rock } \\
\text { of Estonian } \\
\text { soil }^{\mathrm{a}} \\
\end{array}$ & \\
\hline \multicolumn{6}{|l|}{ In graptolite argillite } \\
\hline Uranium, $\mathrm{g} / \mathrm{t}$ & 86 & 36 & 84 & 2.1 & 2.5 \\
\hline $\begin{array}{l}\text { Uranium (prevailing } \\
\text { content), g/t }\end{array}$ & $30-170$ & $20-90$ & $30-160$ & & \\
\hline Thorium, $\mathrm{g} / \mathrm{t}$ & 10 & 8 & 12 & 5.8 & 10.3 \\
\hline Molybdenum, g/t & 162 & 53 & 210 & 0.94 & 1.4 \\
\hline Potassium, $\%$ & 5.9 & 6.2 & 5.1 & 1.86 & 2.86 \\
\hline \multicolumn{6}{|l|}{ In phosphorite } \\
\hline Uranium $^{\mathrm{c}}, \mathrm{g} / \mathrm{t}$ & & 22 & 16 & 2.1 & \\
\hline Thorium, g/t & & 7.4 & 12 & 5.8 & \\
\hline Fluorine, $\mathrm{g} / \mathrm{t}$ & & 12600 & 8400 & 284 & 611 \\
\hline Potassium, \% & & $<0.2$ & $<0.2$ & 1.86 & \\
\hline $\mathrm{P}_{2} \mathrm{O}_{5}, \%$ & & 13 & 8.5 & 0.096 & 0.150 \\
\hline
\end{tabular}

\footnotetext{
${ }^{a}$ In this paper, the generally non-weathered Quaternary deposit (horizon C) is considered as the parent rock of Estonian soil.

${ }^{\mathrm{b}}$ After Wedephol, 1995.

${ }^{\mathrm{c}}$ In deposits, the $\mathrm{U}$ content of phosphorites directly correlates with $\mathrm{P}_{2} \mathrm{O}_{5}$.
} 
K. Jüriado et al.

The position of the northern boundary of the distribution area of graptolite argillite and obolus sandstone (with phosphorite) prior to the continental glaciation is not known, but based on the palaeogeographic conclusions (Männil, 1966), it was several kilometres or even tens of kilometres northward of their present-day outcrop line in the klint escarpment. Thus, several billions of tonnes of U-rich rock material crushed by glaciers have been carried southwards. As a result of the activity of the continental glacier, the U-rich material was mixed with the material with background $U$ concentration, and when the continental glacier retreated, the mixed material mostly deposited on the bedrock surface as till of variable thickness (Petersell et al., 2005).

\section{Methods}

The investigation points were selected so that they would be characteristic of the major potential Rn risk areas and most important lithotypes of the Quaternary cover. Their coordinates were determined by Garmin GPS 76.

Field investigations were carried out in 31 points (Fig. 1). Their position was determined in detail within a circle ca $200 \mathrm{~mm}$ in diameter, considering that the ground surface should be flat, without any visible evidence of technogeneous contamination, and the gamma radiation level (determined with СРП-88H) should be typical for the area. The concentration on $\mathrm{Rn}$ in the investigation points was determined simultaneously by two methods: (1) calculated on the basis of the content of eU (ppm) or ${ }^{226} \mathrm{Ra}(\mathrm{Bq} / \mathrm{kg})$ measured with a portable gamma ray spectrometer $(\mathrm{RnG})$ and $(2)$ by direct measurements of $\mathrm{Rn}\left(\mathrm{kBq} / \mathrm{m}^{3}\right)$ in soil air with a Markus-10 emanometer (RnM) (Petersell et al., 2005).

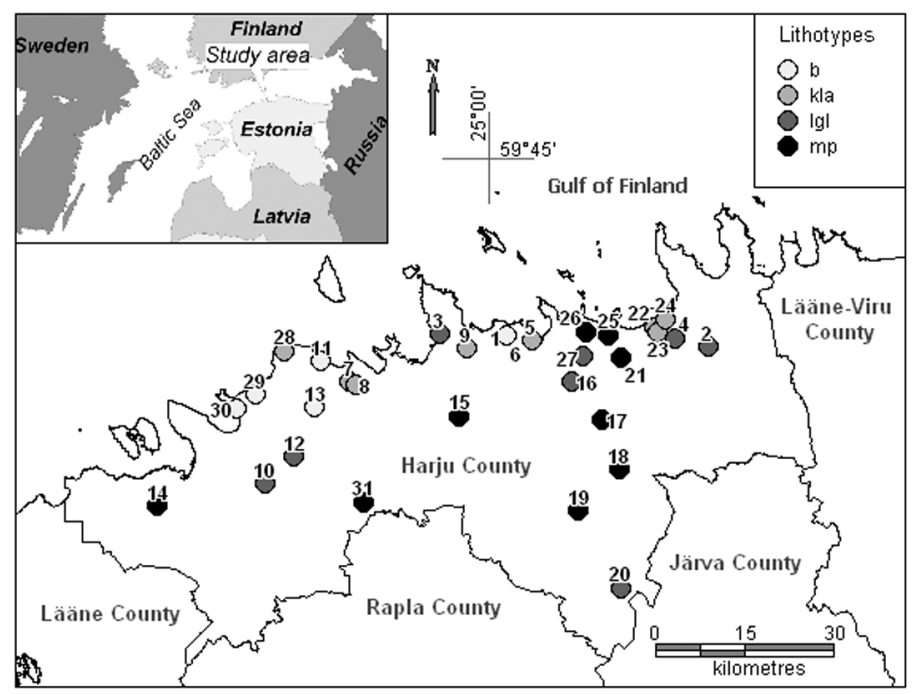

Fig. 1. Study area with investigation points and lithotypes: Holocene marine deposits (b), Fore-klint Lowland and talus deposits (kla), glaciolacustrine deposits (lgl), and till (mp). 
The eU concentration in soil was measured with a portable gamma ray spectrometer (Detector model GPX-21A) at the bottom of the excavations (depth $80 \mathrm{~cm}$, cross-section area ca $20 \mathrm{~cm} \times 20 \mathrm{~cm}$ ). The concentration of Rn in soil air was determined directly with a Markus-10 emanometer at the same depth. Simultaneously, the genetic type of the Quaternary deposit was identified and soil samples were taken from the excavation bottom to determine in the laboratory the concentrations of elements accompanying eU.

Based on the eU concentration measured with the gamma ray spectrometer, the concentration of $\mathrm{Rn}$ in soil air balanced with $\mathrm{Ra}$ was calculated according to the following formula from Clavensjö \& Åkerblom (1994):

$$
\mathrm{RnG}=A e \delta(1-p) p^{-1},
$$

where $\mathrm{RnG}$ is $\mathrm{Rn}$ maximum content developed, $\mathrm{kBq} / \mathrm{m}^{3} ; A$ is eU concentration, $\mathrm{Bq} / \mathrm{kg} ; \quad e$ is Rn emanation factor; $\delta$ is compact volume weight (specific weight), $\mathrm{kg} / \mathrm{m}^{3}$; and $p$ is porosity $(1 \mathrm{~g} / \mathrm{t} \mathrm{eU}=12.35 \mathrm{~Bq} / \mathrm{kg}$; Petersell et al., 2005).

Based on the depth, soil type, and Rn diffusion dependence graph (Clavensjö $\&$ A kerblom, 1994), the results of directly measured Rn concentrations were recalculated to the standard depth of $1 \mathrm{~m}$.

The soil samples collected at the bottom of excavations were dried, the $<2 \mathrm{~mm}$ fraction was separated and ground into powder by quartering. The powder was then sent to AcmeLabs in Canada where the concentrations of approximately 50 elements were determined, including $\mathrm{U}, \mathrm{Th}, \mathrm{K}, \mathrm{P}$, and Mo, which were of special interest for our investigation team. The concentration of $\mathrm{F}$ was determined at the laboratory of the Geological Survey of Estonia. In the investigation area the dispersion of the measured elements was very high and changeable (Table 2), therefore further the geometric mean concentrations and standard coefficients were used to assess the concentrations of elements.

\section{RESULTS AND DISCUSSION}

\section{Concentration of eU}

Different authors have assessed the average concentration of eU in the Earth's crust to be 2.5-3 g/t (Wedephol, 1995). The average concentration of eU in Estonian Quaternary cover is $2.14 \mathrm{~g} / \mathrm{t}$, mostly (68\%) $0.9-4.9 \mathrm{~g} / \mathrm{t}$ (Petersell et al., 2005). Thus in the area under discussion the average eU concentration in soil $6.11 \mathrm{~g} / \mathrm{t}$ - more than twice exceeded the average for the whole Estonian territory, the variation in concentrations was very high, and the maximum concentration reached $19 \mathrm{~g} / \mathrm{t}$ (Fig. 2, Table 2).

The lateral distribution of eU concentrations was very changeable. Unambiguously, the highest eU concentrations occurred in the klint belt, both on its slope and in the Quaternary deposits in front of the escarpment, irrespective of the 
K. Jüriado et al.

Table 2. Results of field measurements and laboratory analyses, arithmetical mean concentrations $\left(\operatorname{Mean}_{\mathrm{A}}\right)$, arithmetical standard deviations $\left(\operatorname{Std~}_{\operatorname{dev}}\right)$, geometrical mean concentrations $\left(\operatorname{Mean}_{\mathrm{G}}\right)$, and geometrical standard deviations $\left(\operatorname{Std} \operatorname{dev}_{\mathrm{G}}\right)$ of the calculated activity and contents of elements in different lithotypes: Fore-klint Lowland and talus deposits (kla), glaciolacustrine deposits (lgl), Holocene marine deposits (b), and till (mp)

\begin{tabular}{|c|c|c|c|c|c|c|c|c|c|c|c|}
\hline \multirow{2}{*}{$\begin{array}{c}\text { Point } \\
\text { num- } \\
\text { ber }\end{array}$} & \multirow[t]{2}{*}{ Lithotype } & \multicolumn{2}{|c|}{ eU content } & \multicolumn{2}{|c|}{$\mathrm{Rn}, \mathrm{kBq} / \mathrm{m}^{3}$} & \multirow{2}{*}{$\begin{array}{l}\mathrm{RnG} / \\
\mathrm{RnM}\end{array}$} & \multicolumn{5}{|c|}{ Content of elements } \\
\hline & & $g / t$ & $\mathrm{~Bq} / \mathrm{kg}$ & $\mathrm{RnG}$ & $\mathrm{RnM}$ & & $\begin{array}{l}\mathrm{U}, \\
\mathrm{g} / \mathrm{t}\end{array}$ & $\begin{array}{l}\mathrm{P}, \\
\%\end{array}$ & $\begin{array}{l}\mathrm{F}, \\
\mathrm{g} / \mathrm{t}\end{array}$ & $\begin{array}{c}\mathrm{Mo}, \\
\mathrm{g} / \mathrm{t}\end{array}$ & $\begin{array}{l}\mathrm{K}, \\
\%\end{array}$ \\
\hline 1 & kla & 10.10 & 124.74 & 149.00 & 15.00 & 9.93 & 8.30 & 2.00 & 3710.00 & 0.70 & 0.35 \\
\hline 2 & $\lg 1$ & 3.70 & 45.70 & 56.00 & 11.00 & 5.09 & 2.90 & 0.13 & 250.00 & 0.10 & 1.60 \\
\hline 3 & $\lg 1$ & 4.20 & 51.87 & 64.00 & 5.00 & 12.80 & 3.10 & 0.46 & 880.00 & 0.30 & 0.86 \\
\hline 4 & $\lg 1$ & 2.90 & 35.82 & 44.00 & 108.00 & 0.41 & 2.50 & 0.58 & 310.00 & 1.90 & 1.47 \\
\hline 5 & kla & 18.10 & 223.54 & 262.00 & 55.00 & 4.76 & 20.40 & 4.25 & 6780.00 & 1.90 & 0.16 \\
\hline 6 & $\mathrm{~b}$ & 9.30 & 114.86 & 138.00 & 17.00 & 8.12 & 7.80 & 2.20 & 4030.00 & 0.70 & 0.27 \\
\hline 7 & kla & 8.10 & 100.04 & 119.00 & 98.00 & 1.21 & 7.60 & 0.57 & 104.00 & 1.80 & 1.91 \\
\hline 8 & kla & 5.50 & 67.93 & 81.00 & 31.00 & 2.61 & 6.70 & 0.28 & 660.00 & 0.40 & 2.16 \\
\hline 9 & kla & 12.70 & 156.85 & 187.00 & 86.00 & 2.17 & 11.10 & 1.54 & 3150.00 & 2.00 & 0.23 \\
\hline 10 & $\lg 1$ & 2.10 & 25.94 & 32.00 & 24.00 & 1.33 & 2.60 & 0.05 & 470.00 & 0.20 & 2.49 \\
\hline 11 & $\mathrm{~b}$ & 12.40 & 153.14 & 184.00 & 195.00 & 0.94 & 12.10 & 2.17 & 286.00 & 5.30 & 0.30 \\
\hline 12 & $\lg 1$ & 2.00 & 24.70 & 30.00 & 66.00 & 0.45 & 2.00 & 0.03 & 260.00 & 0.50 & 2.27 \\
\hline 13 & $\mathrm{~b}$ & 5.10 & 62.99 & 76.00 & 53.00 & 1.43 & 5.20 & 0.49 & 1030.00 & 0.20 & 0.85 \\
\hline 14 & $\mathrm{mp}$ & 2.00 & 24.70 & 28.00 & 94.00 & 0.30 & 1.30 & 0.04 & 200.00 & 0.10 & 1.07 \\
\hline 15 & $\mathrm{mp}$ & 4.90 & 60.52 & 69.00 & 38.00 & 1.82 & 3.00 & 0.11 & 270.00 & 1.00 & 1.67 \\
\hline 16 & $\operatorname{lgl}$ & 3.00 & 37.05 & 46.00 & 35.00 & 1.31 & 2.50 & 0.14 & 260.00 & 0.60 & 2.08 \\
\hline 17 & $\mathrm{mp}$ & 1.90 & 23.47 & 27.00 & 47.00 & 0.57 & 1.50 & 0.06 & 230.00 & 0.20 & 1.69 \\
\hline 18 & $\mathrm{mp}$ & 0.90 & 11.12 & 13.00 & 12.00 & 1.08 & 1.50 & 0.06 & 240.00 & 0.40 & 1.69 \\
\hline 19 & $\mathrm{mp}$ & 1.40 & 17.29 & 20.00 & 11.00 & 1.82 & 1.40 & 0.05 & 240.00 & 0.30 & 1.64 \\
\hline 20 & $\operatorname{lgl}$ & 2.50 & 30.88 & 38.00 & 73.00 & 0.52 & 2.70 & 0.06 & 250.00 & 0.30 & 2.49 \\
\hline 21 & $\mathrm{mp}$ & 4.10 & 50.64 & 58.00 & 90.00 & 0.64 & 3.20 & 0.21 & 510.00 & 0.50 & 2.08 \\
\hline 22 & kla & 8.70 & 107.45 & 128.00 & 263.00 & 0.49 & 6.70 & 1.03 & 1730.00 & 3.20 & 1.13 \\
\hline 23 & kla & 6.90 & 85.22 & 102.00 & 93.00 & 1.10 & 5.80 & 1.11 & 2430.00 & 0.80 & 0.59 \\
\hline 24 & kla & 12.20 & 150.67 & 180.00 & 184.00 & 0.98 & 10.80 & 1.18 & 1120.00 & 7.70 & 0.96 \\
\hline 25 & $\mathrm{mp}$ & 8.20 & 101.27 & 116.00 & 40.00 & 2.90 & 6.40 & 0.76 & 1490.00 & 1.90 & 0.94 \\
\hline 26 & $\mathrm{mp}$ & 9.60 & 118.56 & 136.00 & 111.00 & 1.23 & 9.70 & 0.42 & 910.00 & 12.50 & 2.03 \\
\hline 27 & $\operatorname{lgl}$ & 2.90 & 35.82 & 44.00 & 82.00 & 0.54 & 2.50 & 0.15 & 350.00 & 0.20 & 1.74 \\
\hline 28 & kla & 19.00 & 234.65 & 280.00 & 198.00 & 1.41 & 16.80 & 1.01 & 2090.00 & 14.30 & 2.84 \\
\hline 29 & $\mathrm{~b}$ & 2.00 & 24.70 & 30.00 & 54.00 & 0.56 & 1.40 & 0.13 & 190.00 & 0.10 & 0.30 \\
\hline 30 & $\mathrm{~b}$ & 2.10 & 25.94 & 31.00 & 35.00 & 0.89 & 1.70 & 0.10 & 250.00 & 0.40 & 0.55 \\
\hline 31 & $\mathrm{mp}$ & 1.00 & 12.35 & 14.00 & 38.00 & 0.37 & 1.20 & 0.03 & 300.00 & 1.10 & 1.98 \\
\hline & $\operatorname{Mean}_{\mathrm{A}}$ & 6.11 & 75.49 & 89.74 & 72.97 & 2.25 & 5.56 & 0.69 & 1128.39 & 1.99 & 1.37 \\
\hline & Std $\operatorname{dev}_{\mathrm{A}}$ & 4.90 & 60.49 & 71.63 & 62.86 & 2.97 & 4.79 & 0.93 & 1503.18 & 3.46 & 0.78 \\
\hline & Min & 0.90 & 11.12 & 13.00 & 5.00 & 0.30 & 1.20 & 0.03 & 104.00 & 0.10 & 0.16 \\
\hline & Max & 19.00 & 234.65 & 280.00 & 263.00 & 12.80 & 20.40 & 4.25 & 6780.00 & 14.30 & 2.84 \\
\hline & $\operatorname{Mean}_{\mathrm{G}}$ & 4.43 & 54.74 & 65.12 & 49.85 & 1.31 & 4.00 & 0.28 & 591.43 & 0.74 & 1.07 \\
\hline & Std $\operatorname{dev}_{\mathrm{G}}$ & 2.32 & 2.32 & 2.33 & 2.61 & 2.67 & 2.28 & 4.29 & 3.01 & 3.91 & 2.26 \\
\hline & $\begin{array}{l}\text { Limit of safe } \\
\text { concen- } \\
\text { tration }\end{array}$ & $\sim 3.6$ & $\sim 45$ & 50 & 50 & & 20 & & 450 & 10 & \\
\hline
\end{tabular}




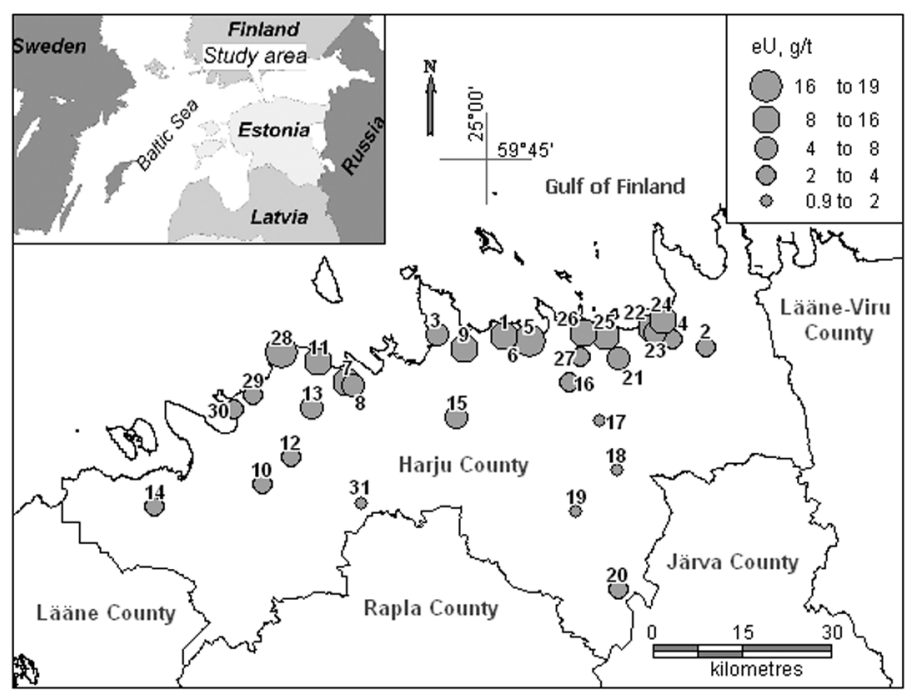

Fig. 2. Concentration of eU in soil air.

lithotype. Southwards, the eU concentration in Quaternary deposits gradually decreased. Near the klint escarpment in the till (investigation point No. 26) the eU concentration was $9.6 \mathrm{~g} / \mathrm{t}$, but in the carbonate-rich till in the southern part of the study area (investigation point No. 18) it was less than $1 \mathrm{~g} / \mathrm{t}$.

The highest eU concentrations, ranging from $5.5-19.0 \mathrm{~g} / \mathrm{t}$, were observed in the talus slope of the klint escarpment and in the deposits of its intermediate escarpments. As for lithotypes, the highest eU concentrations were related to fore-klint and klint slope deposits (Table 3). The concentration of eU in the talus deposit more than twice exceeded the average concentration of the area, characterizing the generally high but extremely variable share of the material originating from graptolite argillite and obolus phosphorite. Besides, the eU concentration was changeable and frequently high in the sand and silt of different Baltic Sea development stages (Table 3), reaching even $12.4 \mathrm{~g} / \mathrm{t}$ in the sand in front of the klint escarpment (investigation point No. 11). It reflects wave erosion of the klint escarpment, but also an increased content of granitoid material of the rapakivi formation. Generally, the concentration of eU was lower in glaciolacustrine deposits and carbonate-rich till; however, patches with higher eU concentration occurred within these deposits as well.

\section{Radon in soil air}

The concentration of $\mathrm{Rn}$ in soil air was determined by two methods: calculated on the basis of the eU concentration in soil $(\mathrm{RnG})$ and the $\mathrm{Rn}$ preserved in soil air was directly measured $(\mathrm{RnM})$. As $\mathrm{Rn}$ is a direct decay product of eU, there is 


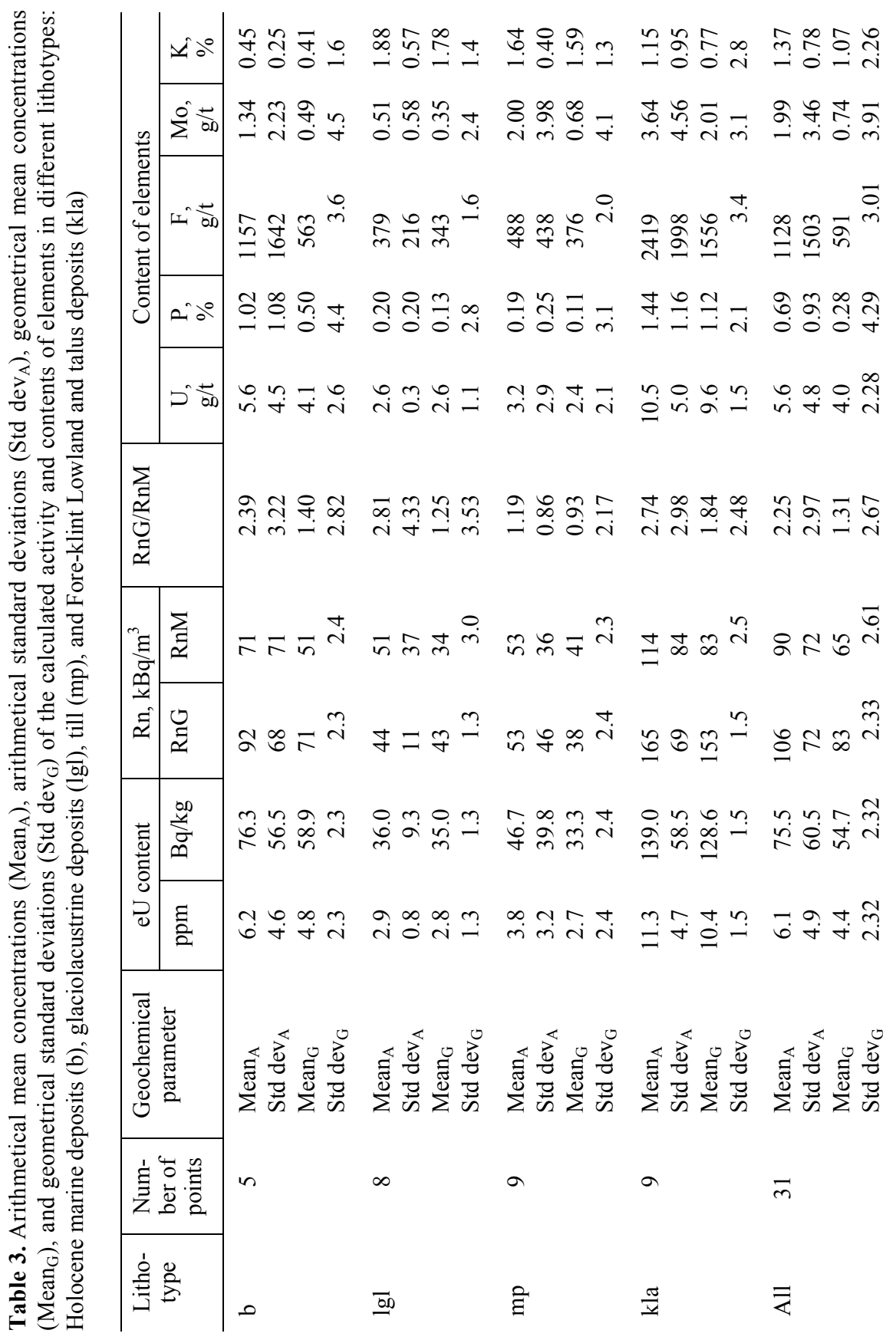


an unambiguous correlation between the soil's eU concentration and the generated $\mathrm{Rn}$ concentration (RnG), which is influenced only by the variable emanation capacity of lithotypes. Studies have shown that only $20-35 \%$ of the Rn formed as a result of Ra decay in grains of soils emanates into soil air (Petersell et al., 2005). The emanation coefficient of finer-grained lithotypes was higher, but in general the concentration of $\mathrm{Rn}$ formed in soil air followed the distribution and regularities of $\mathrm{eU}$ in soil.

\section{Concentration of Rn formed in soil air by Ra decay}

The concentration of $\mathrm{Rn}$ in soil air calculated from the eU concentration $(\mathrm{RnG})$ characterizes the Rn concentration level that has developed in a closed system with no soil air aeration or additional $\mathrm{Rn}$ inflow from deeper soil or bedrock layers.

In Harju County the RnG concentration in soil air well correlated with the eU concentration in soil (Table 4). The highest concentrations (up to $280 \mathrm{kBq} / \mathrm{m}^{3}$ ) occurred on the Fore-klint Lowland and in the distribution area of talus deposits, and the lowest $\left(\mathrm{RnG}<13 \mathrm{kBq} / \mathrm{m}^{3}\right)$ in carbonate-rich till. Tables 2 and 3 present the concentrations of $\mathrm{RnG}$ in different lithotypes of the study area.

Figure 3 presents the areal distribution of RnG concentrations in the study area, which is close to the distribution of eU concentrations (Fig. 2).

The concentration of $\mathrm{RnG}$ varied considerably, from 13 to $280 \mathrm{kBq} / \mathrm{m}^{3}$ with the average being $90 \mathrm{kBq} / \mathrm{m}^{3}$, which exceeds threefold the average value for Estonian soils $\left(27 \mathrm{kBq} / \mathrm{m}^{3}\right.$; Petersell et al., 2005) and is 1.8 times higher than the maximum permissible concentration for construction activity without applying $\mathrm{Rn}$ protection measures $\left(50 \mathrm{kBq} / \mathrm{m}^{3}\right.$; Eesti Standardikeskus, 2009).

\section{Residual concentration of Rn in soil air}

Although the concentration of Rn formed from eU was stable in soil air, the natural soils are not a closed system and some $\mathrm{Rn}$ formed as a Ra decay product

Table 4. Correlation of $U$ with main accompanying contaminants

\begin{tabular}{l|c|c|c|c|c|c|c|c}
\hline All & \multicolumn{1}{c|}{$\mathrm{eU}$} & $\mathrm{RnG}$ & $\mathrm{RM}$ & $\mathrm{U}$ & $\mathrm{P}$ & $\mathrm{F}$ & $\mathrm{Mo}$ & $\mathrm{K}$ \\
\hline $\mathrm{eU}$ & 1 & & & & & & & \\
$\mathrm{RnG}$ & 1 & 1 & & & & & & \\
$\mathrm{RnM}$ & 0.510 & 0.514 & 1 & & & & & \\
& & & & & & & & \\
$\mathrm{U}$ & 0.979 & 0.978 & 0.454 & 1 & & & & \\
$\mathrm{P}$ & 0.803 & 0.803 & 0.221 & 0.834 & 1 & & & \\
$\mathrm{~F}$ & 0.719 & 0.716 & 0.023 & 0.738 & 0.895 & 1 & & \\
Mo & 0.663 & 0.660 & 0.634 & 0.629 & 0.212 & 0.129 & 1 & \\
K & -0.299 & -0.301 & 0.016 & -0.273 & -0.609 & -0.526 & 0.199 & 1
\end{tabular}


K. Jüriado et al.

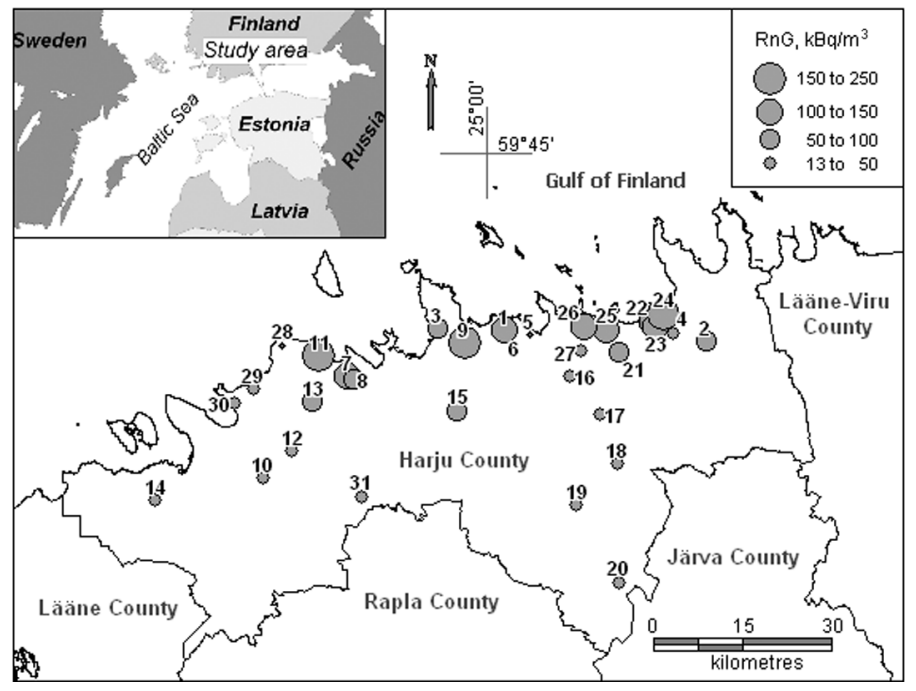

Fig. 3. Concentration of RnG in soil air.

emanates into air. At he same time, Rn may accrue to soil air also from deeper soil/bedrock layers. Such so-called residual concentration of Rn (RnM) generally follows the same regularities as the concentrations formed from $\mathrm{eU}$ in soil. Although the average concentrations of RnG and RnM in soil air of the region were generally similar (Fig. 3), differences in their areal distribution are notable (Figs 3-6; Tables 2, 3).

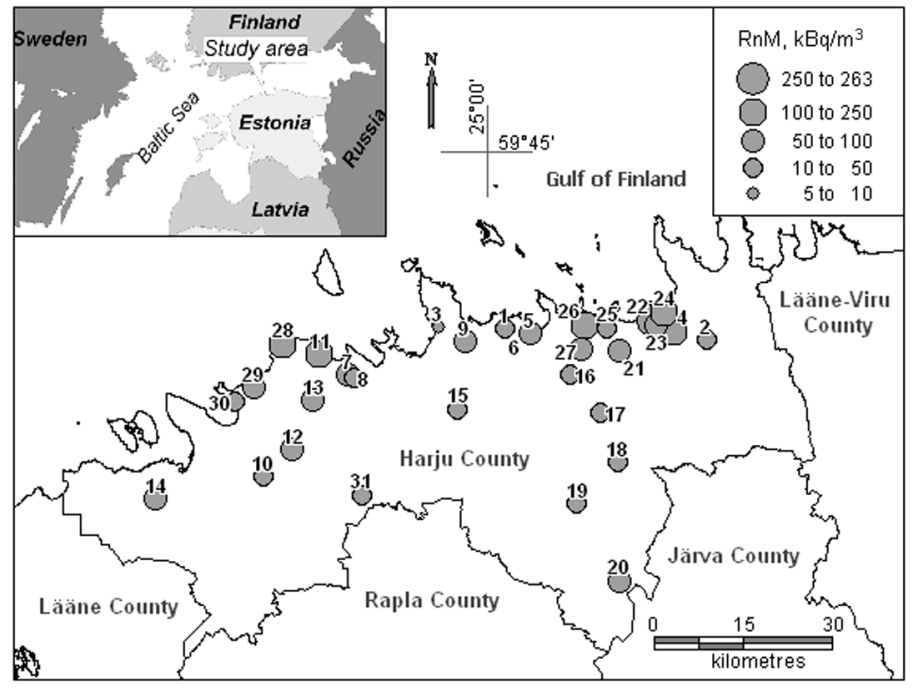

Fig. 4. Concentration of RnM in soil air. 


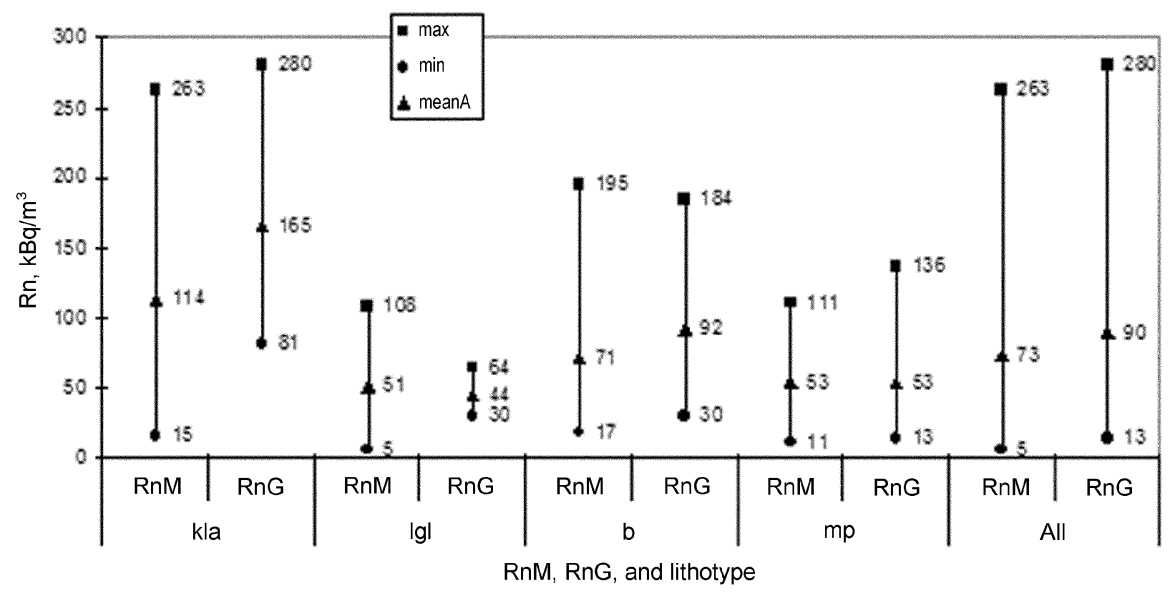

Fig. 5. Maximum, minimum, and mean values of RnG and RnM in different lithotypes: Fore-klint Lowland and talus deposits (kla), glaciolacustrine deposits (lgl), Holocene marine deposits (b), and till (mp).

Investigations carried out in Sweden (Clavensjö \& Åkerblom, 1994) showed that when a humus horizon has developed on the ground surface, at a depth of $1 \mathrm{~m}$ the concentration of RnM forms $50-90 \%$ of the Rn formed from eU. Figure 7 presents the concentrations of $\mathrm{Rn}$ in soil air calculated on the basis of eU (RnG) as well as those measured with a Markus-10 (RnM) in various lithotypes. In general, the observation points with high RnM values were located on the flat fore-klint area in front of the klint escarpment, as well as in talus deposits and on

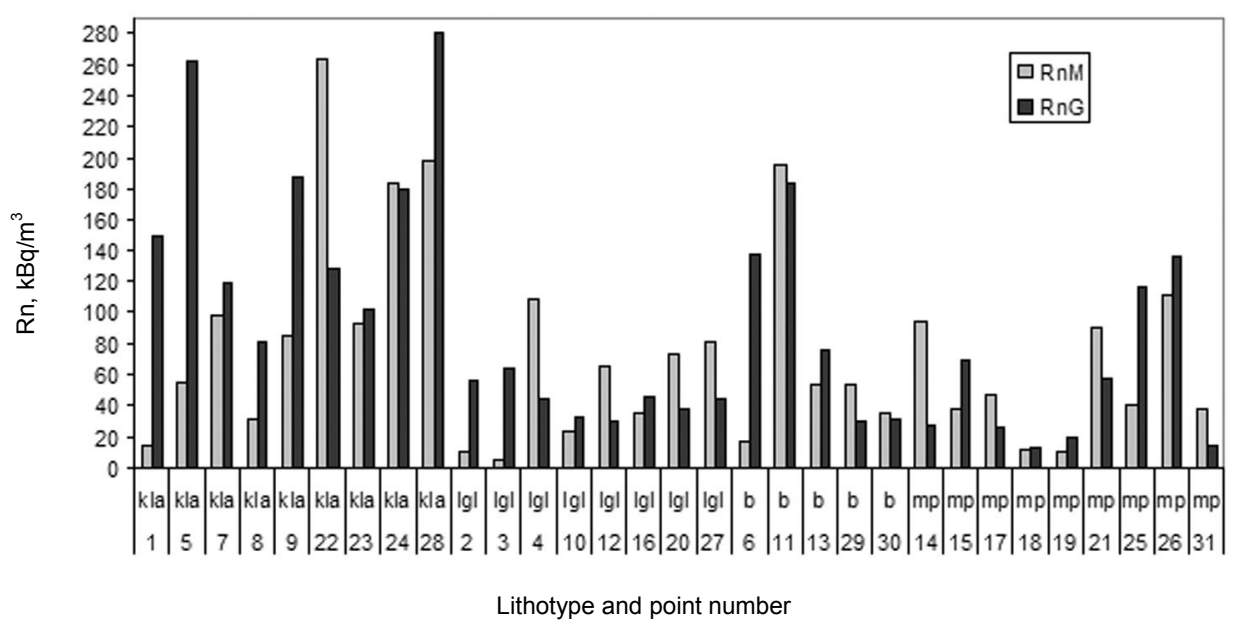

Fig. 6. Concentrations of RnG and RnM in the soil air of different lithotypes: Fore-klint Lowland and talus deposits (kla), glaciolacustrine deposits ( $\operatorname{lgl})$, Holocene marine deposits (b), and till (mp). 


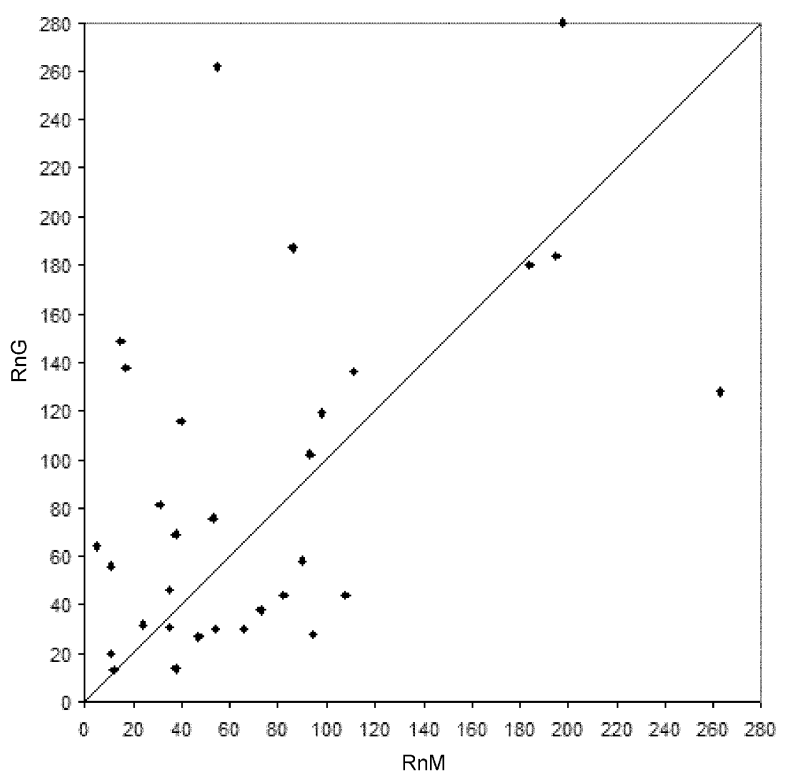

Fig. 7. Concentrations of $\mathrm{Rn}$ in soil air calculated after eU (RnG) vs concentrations measured by Markus-10 (RnM).

the slopes of ancient valleys. Some high RnM concentrations in soil air were found also outside these areas.

A characteristic feature was that in some investigation points the RnM concentration in the soil air was several times lower than could be assumed from the concentration of eU, while in others RnM concentrations many times exceeded those suggested by the concentrations of eU (Fig. 6). In the former case, the sandy soil with a high eU concentration was covered by a very poorly developed humus horizon (e.g. investigation point No. $6, \mathrm{RnG}=138 \mathrm{kBq} / \mathrm{m}^{3} ; \mathrm{RnM}=17 \mathrm{kBq} / \mathrm{m}^{3}$ ). The latter case (e.g. investigation point No. $14, \mathrm{RnG}=28 \mathrm{kBq} / \mathrm{m}^{3} ; \mathrm{RnM}=94 \mathrm{kBq} / \mathrm{m}^{3}$ ) was observed when the soil with a background eU concentration was overlain by a dense and thick $(>20 \mathrm{~cm})$ humus horizon and there existed an additional inflow of Rn from graptolite argillite and obolus phosphorite lying at a depth of 65-75 m. Our investigation showed that in the soil air of the limestone fissures of the alvar areas on the limestone plateaus in Harju County the concentration of Rn reached up to $96 \mathrm{kBq} / \mathrm{m}^{3}$.

As mentioned above, the Palaeozoic sedimentary rocks have a southward dipping of about $3 \mathrm{~m} / \mathrm{km}$. Consequently, in the distribution area of soils with a background eU concentration high concentrations of $\mathrm{Rn}$ of deep origin (investigation point No. 20, RnM $=73 \mathrm{kBq} / \mathrm{m}^{3}$ ) were observed even in areas where rocks with a high content of $U$ lie at a depth of more than $100 \mathrm{~m}$ below ground surface. Such distribution of eU content by areas and lithotypes indicates its 
direct connection with the U-rich rocks exposed in the klint escarpment. Although it is obvious that continental glaciers carried their clasts and smalls to the south and sea abrasion and accumulation to the north, precise elucidation of their distribution in the Quaternary deposits can be done only by detailed geochemical mapping.

The reasons of the above-described phenomena are variable. Often graptolite argillite or phosphorite layers crop out beneath talus deposits in front of the klint as well as in the slopes of valleys and in fore-klint flat areas, or clasts or fines of graptolite argillite or phosphorite occur in deeper layers of deposits. Such areas present health hazards to residents. These are common in the intermediate klint plateaus (e.g. at Suurupi, Rannamõisa, Tiskre, Jõelähtme, etc.). The $\mathrm{Rn}$ potential of graptolite argillite and obolus phosphorite can be high, depending on the concentration of eU in rocks, reaching up to $1400 \mathrm{kBq} / \mathrm{m}^{3}$ in graptolite argillite and up to $400 \mathrm{kBq} / \mathrm{m}^{3}$ in obolus phosphorite. In massive rock bodies as a maximum $10 \%$ of the $\mathrm{Rn}$ formed in them is mobile, but in fissured rocks or when crushed in the process of construction activity or when the varieties rich in clasts or fines of graptolite argillite and phosphorite are present, they may become hazardous sources of migrating Rn (e.g. observation point No. 22).

\section{Origin}

As was mentioned above, in the study area the main sources of high Rn concentrations in soil air are the Lower-Ordovician U-rich rocks, graptolite argillite, and obolus sandstone (phosphorite), and among the Quaternary deposits, clasts and fines of the above-mentioned rocks and to a lesser extent the Quaternary deposits enriched with erratic granitoid material of the rapakivi formation.

In addition to $\mathrm{U}$, graptolite argillite is also rich in $\mathrm{K}$ and environmentally harmful elements Mo, V, As, etc. In phosphorite the content of these elements is small, but the content of $\mathrm{F}$ is high.

Consequently, in high Rn-risk areas the concentrations of Mo, F, and other elements listed above exceed the safe limit for residence and can cause health problems. The connections between $\mathrm{U}$ and accompanying hazardous elements are reflected in their correlations (Table 4).

There is a distinct positive correlation between RnG, eU, U, P, F, and Mo. The correlation between RnM and RnG and other listed elements is mostly positive, but frequently also neutral, reflecting the discrepancies between RnM and RnG in observation points.

The content of the elements in graptolite argillite and phosphorite associations is closely entwined. Such entwinement, but a rather regular relationship with $\mathrm{U}$, can be seen on the ABC diagrams of elements (Fig. 8).

In soil the characteristic high $\mathrm{K}$ content in graptolite argillite is supplemented with $\mathrm{K}$ from granite and other rocks. As a result, $\mathrm{K}$ is neutral towards the observed environmentally hazardous elements or is negatively correlated. 


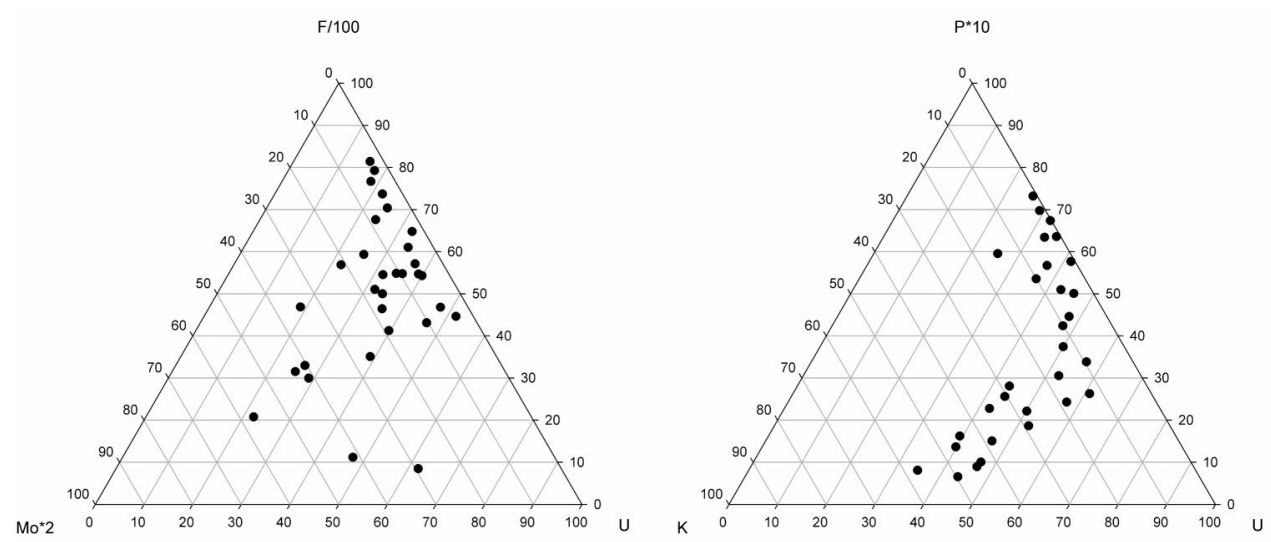

Fig. 8. ABC diagrams of some elements.

\section{CONCLUSIONS}

In Harju County the concentration of Rn in soil air was high $\left(>50 \mathrm{kBq} / \mathrm{m}^{3}\right)$ or very high $\left(>250 \mathrm{kBq} / \mathrm{m}^{3}\right)$, and its distribution was heterogeneous. The concentration of Rn several times exceeded the average values of Estonian soil and the Earth's crust. The reason is presence of U-rich graptolite argillite and obolus phosphorite in the geological sequence and distribution of their clasts and fines in Quaternary deposits. The concentration of Rn was especially high in the klint zone where graptolite argillite and phosphorite are exposed or directly underlie the Quaternary cover, or the Quaternary deposits rich in clasts and fines of these rocks are present.

The concentration of $\mathrm{Rn}$ calculated from eU in soil air was temporally stable and well correlated with the concentration of eU as well as $\mathrm{U}$, and was somewhat variable by lithotypes.

The natural soil in the study area is not a closed system and therefore the Rn formed by Ra decay partly migrates to air. At the same time, an additional inflow of Rn into soil air occurs from lower graptolite argillite and phosphorite beds. Thus, the concentration of Rn measured with a Markus- 10 is actually residual concentration. Although it generally followed the same regularities as the concentration of $\mathrm{Rn}$ formed from $\mathrm{eU}$ in soil, there were considerable discrepancies in the lateral distribution. Depending on the location of the investigation point, type of Rn source, aeration properties of soils, time of measuring, moisture content, and some other factors, the results obtained by the two methods used considerably differed. In case $\mathrm{Rn}$ sources are present, additional Rn may migrate into soil air from a depth of $100 \mathrm{~m}$ and even from greater depths.

The soils beneath dwellings and their nearest surroundings with a high concentration of $\mathrm{Rn}$ or $\mathrm{Rn}$ formed in the bedrock under the Quaternary deposits serve as the main sources of $\mathrm{Rn}$ in indoor air of dwellings. 
The high and very high Rn-risk areas did not follow the distribution of geneticlithologic types of Quaternary deposits. Outlining these and elucidating their Rn-risk level can be performed only by detailed measurements with applying two parallel methods: calculated from the eU concentration and directly measured with a Markus-10 in soil air.

In the high Rn-risk areas within the klint zone there were some investigation points where the content of U, F, Mo, and other elements exceeded the recommended and even permissible level for residential areas.

\section{ACKNOWLEDGEMENTS}

The authors are grateful to the reviewers for constructive comments and suggestions on the manuscript.

\section{REFERENCES}

Clavensjö, B. \& Åkerblom, G. 1994. The Radon Book. Measures Against Radon. The Swedish Council for Building Research, Stockholm.

Eesti Standardikeskus. 2009. EVS Eesti Standard 840 : 2009. Radooniohutu hoone projekteerimine. Eesti Standardikeskus, Tallinn (in Estonian).

Geological Survey of Finland. 1992. The Geochemical Atlas of Finland. Part 2; Till. Geological Survey of Finland, Espoo.

Männil, R. M. 1966. Evolution of the Baltic Basin in the Ordovician. Valgus, Tallinn (in Russian).

Miidel, A. \& Tavast, E. 1978. Eesti mattunud orud. Eesti Loodus, 2, 105-110 (in Estonian).

Mjönes, L. \& Falk, R. 2005. Cancer risk from radon in indoor air and drinking water in Sweden. The Swedish Radiation Protection Authority's risk assessment. In The Natural Radiation Environment VII: Seventh International Symposium on the Natural Radiation Environment (NRE-VII) 20-24 May 2002, Rhodes, Greece (Mc Laughlin, J. P., Simopoulos, E. S. \& Steinhäusler, F., eds), pp. 604-611.

Naturally Occurring Radioactivity in the Nordic Countries - Recommendations. 2000. The Radiation Protection Authorities in Denmark, Finland, Iceland, Norway and Sweden. https://www.sst.dk/ /media/Sundhed\%20og\%20forebyggelse/Straalebeskyttelse/SIS/Radon /Nordisk_flag_2000.ashx (visited 2011-05-10).

Petersell, V., Åkerblom, G., Ek, B.-M., Enel, M., Mõttus, V. \& Täht, K. 2005. Radon Risk Map of Estonia: Explanatory Text to the Radon Risk Map Set of Estonia at Scale of 1:500 000. Report 2005 : 16. Swedish Radiation Protection Authority (SSI), Tallinn.

Petersell, V., Täht-Kok, K. \& Karimov, M. 2008. Harjumaa radooniriski kaart, M. 1: 200000. Map in the Estonian Geological Fund, Tallinn (in Estonian).

Raukas, A. \& Tavast, E. 1987. Eesti mattunud orgude ehitusest. In Eesti Geograafia Seltsi aastaraamat 1981/1982. 20, pp. 5-15. Tallinn (in Estonian with Russian and English summaries).

Raukas, A. \& Teedumäe, A. (eds). 1997. Geology and Mineral Resources of Estonia. Institute of Geology, Estonian Academy Publishers, Tallinn.

Vaher, R., Miidel, A., Raukas, A. \& Tavast, E. 2010. Ancient buried valleys in the city of Tallinn and adjacent area. Estonian J. Earth Sci., 59, 37-48.

Wedephol, K. H. 1995. The composition of the continental crust. Geochim. Cosmochim. Acta, 59, $1217-1232$. 


\title{
Radooniemissioonid Harjumaal
}

\author{
Krista Jüriado, Valter Petersell ja Anto Raukas
}

Harju maakonna pinnaseõhu radoonisisaldus on sageli kõrge $\left(>50 \mathrm{kBq} / \mathrm{m}^{3}\right)$ või väga kõrge $\left(>250 \mathrm{kBq} / \mathrm{m}^{3}\right)$, ületades mitu korda maailma ja ka Eesti pinnase keskmise. Põhjuseks on kõrge uraanisisaldusega graptoliitargilliidi ja fosforiidi esinemine geoloogilises läbilõikes ning nende purru ja peenese esinemine pinnakattes. Eriti kõrge on radoonisisaldus klindivööndis, kus esineb graptoliitargilliidi ja oobolusfosforiidi paljandeid, nende purru- ning peeneserikkaid kvaternaarisetete erimeid või nende avamus on vahetult pinnakatte all.

eU-sisalduse järgi pinnaseõhus kujunev arvutuslik radoonisisaldus on ajas stabiilne ja heas korrelatsioonis pinnases eU- ning samuti uraanisisaldusega ja litotüüpide lõikes mõnevõrra erinev.

Raadiumi lagunemisel tekkivast radoonist haihtub osa õhku. Samas lisandub radooni pinnaseõhku sügavamal lasuvatest kivimitest. Seega on Markus 10-ga mõõdetud radoonisisaldus tegelikult jääksisaldus. Kuigi see jälgib pinnaseõhus üldjoontes samu seaduspärasusi nagu pinnases eU-st kujunev radoonisisaldus, esineb pindalalises levikus olulisi erinevusi. Sõltuvalt uuringupunkti asukohast, radooniallika tüübist, pinnase aeratsiooniomadustest, mõõtmise ajast, niiskusest ja teistest tingimustest võivad kahe meetodiga saadud mõõtmistulemused oluliselt erineda. Kõrge või väga kõrge radoonisisaldusega majadealune ja selle vahetu ümbruse pinnas ning (või) viimase all aluspõhjakivimites tekkiv radoon on majade siseõhu peamine radooniallikas.

Need kõrge ja eriti kõrge radoonisisaldusega alad ei järgi kvaternaarisetete geneetilis-litoloogiliste tüüpide levilaid. Viimaste kontuurimine ja nende piires radooniriski taseme selgitamine on reaalne ainult detailsete otsemõõtmiste tulemusel, paralleelselt kahe meetodiga, pinnases eU-sisalduse järgi arvutatult ja pinnaseõhus Markus 10-ga otsemõõdetult.

Klindivööndis kõrge radooniriski aladel esineb uuringupunkte, mille pinnases ületab uraani-, fluori-, molübdeeni- jt sisaldus alalistes elurajoonides soovitusliku ja isegi lubatu taseme. 